\title{
SILENT AND SURPRISING PATHOLOGY: APPENDIX TUMORS-INCIDENTAL FINDING OF A RARE MUCINOUS APPENDICEAL ADENOCARCINOMA
}

\author{
Ailenei Mihaela-Cristina ${ }^{1}$, Călin Roxana ${ }^{1}$, Prună Mădălina ${ }^{1}$, Mitru Cătălinn ${ }^{1}$, Jinga Mariana ${ }^{1,2}$, \\ Ioniță-Radu Florentina ${ }^{1,3}$, Sandu Cristina ${ }^{1}$, Bucurică Săndica ${ }^{1,2}$ \\ ${ }^{1}$ Spitalul Universitar de Urgență Militar Central "Dr. Carol Davila" București \\ ²Universitatea de Medicină și Farmacie Carol Davila București \\ ${ }^{3}$ Facultatea de Medicină Universitatea Titu Maiorescu \\ Corresponding author: Bucurică Săndica \\ e-mail: bucuricasandy@yahoo.com
}

\begin{abstract}
Appendiceal epithelial tumors are a rare finding in comparison with the incidence of colorectal cancer that is approximately 100-fold higher. As appendiceal neoplasms and colorectal cancer have a different clinical and tumoral behavior, these tumors are classified separately in the various tumor classifications. Most appendiceal neoplasms are found during surgery or postoperatively in appendectomy specimens. Given the possibility of neoplastic peritoneal dissemination, the lack of symptoms is a serious problem.

However, the percentage of appendiceal tumors that is incidentally discovered by imaging is increasing over time. Primary adenocarcinoma of the appendix is exceedingly rare and frequently has an extremely poor prognosis because it is diagnosed in advanced stages.

Keywords: mucinous adenocarcinoma, appendiceal tumors, incidental finding, ultrasound

\section{Rezumat}

Tumorile apendiceale primare reprezintă o descoperire foarte rară comparativ cu incidența cancerului colorectal, care este de aproape 100 de ori mai mare. Întrucât neoplazia apendicelui și cancerul colorectal au comportamente clinice și tumorale diferite, sunt clasificate adeseori separat. Majoritatea cancerelor de apendice sunt descoperite intraoperator sau postoperator la pacienții cu apendicectomie. Având în vedere posibilitatea diseminării peritoneale, lipsa simptomatologiei este o problemă serioasă.

în decursul timpului a crescut procentul de depistare incidental a acestor tumori prin imagistică, însă adenocarcinomul primar apendiceal este extrem de rar și are prognostic nefavorabil deoarece este diagnosticat în stadii tardive.
\end{abstract}

Cuvinte cheie: adenocarcinom mucinos, tumori apendiceale, descoperire întâmplătoare, ecografie. 


\section{INTERNAL}

\section{Clinical cases}

\section{Introduction}

Appendiceal epithelial tumors are a rare finding in comparison with the incidence of colorectal cancer that is approximately 100fold higher. As appendiceal neoplasms and colorectal cancer have a different clinical and tumor behavior, these tumors are classified separately in the various tumor classifications. Most appendiceal neoplasms are found during surgery or postoperatively in appendectomy specimens. However, the percentage of appendiceal tumors that is incidentally discovered by imaging is increasing over time. A clinical diagnosis is difficult due to a variable symptomatology in patients, ranging from an asymptomatic course, to vague acute or chronic abdominal complaints, even with symptoms mimicking acute appendicitis.

Appendiceal mucinous adenocarcinomas are defined as mucinous neoplasms comprised of $>50 \%$ extracellular mucin, with the presence of infiltrative invasion of the appendix. In 2012, Peritoneal Surface Oncology Group International (PSOGI) classification sorted appendiceal mucinous lesions into non-neoplastic appendiceal mucinous (simple mucoceles) and neoplastic appendiceal mucinous lesions (serrated polyps of the appendix, mucinous appendiceal neoplasm, mucinous adenocarcinomas of the appendix). The mucinous adenocarcinomas can be classified as well, moderately, and poorly differentiated, although the histologic criteria for the different grading systems are not well-established. The presence of signet ring cells in the lesion to whatever extent indicates a poorly differentiated carcinoma. If more than $50 \%$ of the tumor consists of signet ring cells, the term signet ring cell carcinoma is used. Otherwise, if less than $50 \%$ of the cells have signet ring cell morphology, the tumor is classified as poorly differentiated adenocarcinoma with signet ring cells.

Mucinous adenocarcinomas develop mainly from precursor lesions. Patients are generally young, with a median age of 50 to 60 years, and many patients already present with synchronous metastatic disease, especially in the case of signet ring cell adenocarcinomas, frequently with nodal metastases, in contrast to patients with lowgrade mucinous appendiceal neoplasm (LAMN). Mucinous and signet ring cell adenocarcinomas metastasize intra- and extraperitoneal, but usually intra-abdominal dissemination occurs first. Survival is strongly dependent of histologic grade. Among appendiceal adenocarcinomas, mucinous adenocarcinoma has the most favorable prognosis, with a median survival of over 60 months. The most worrying complication of appendiceal mucinous 


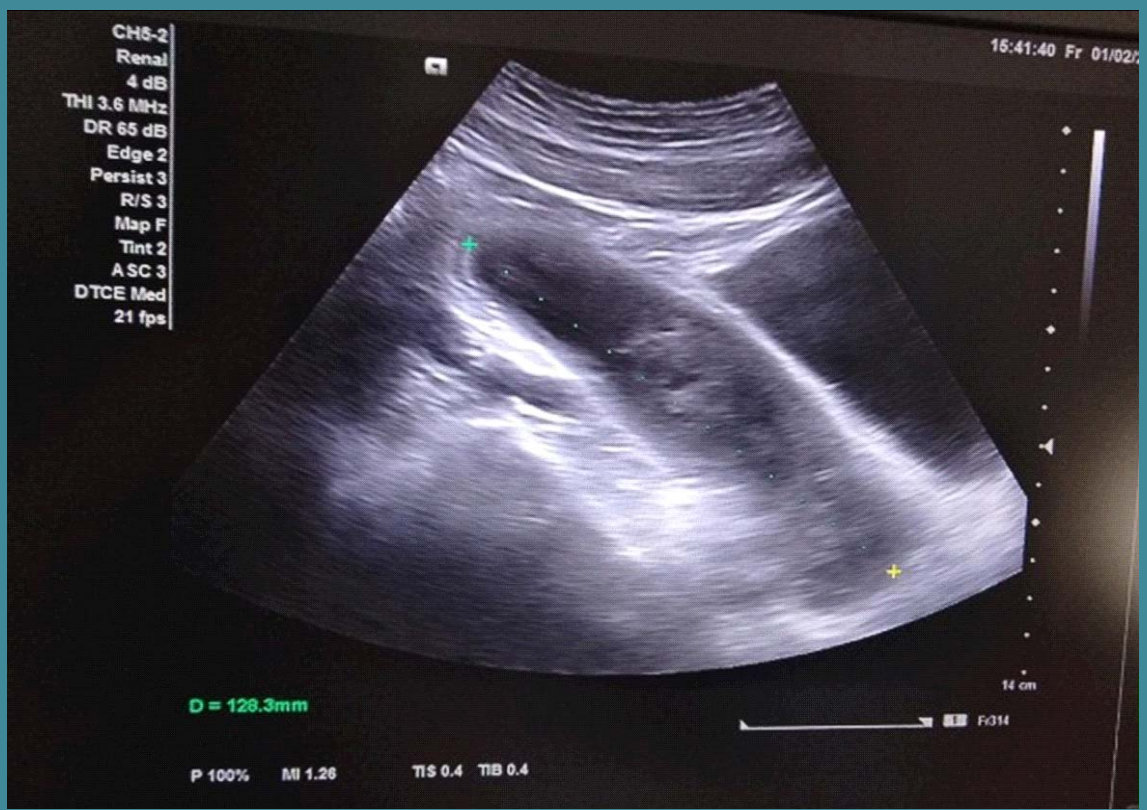

Figure 1. Abdominal ultrasound of the incidental lesion- retrovesical localisation

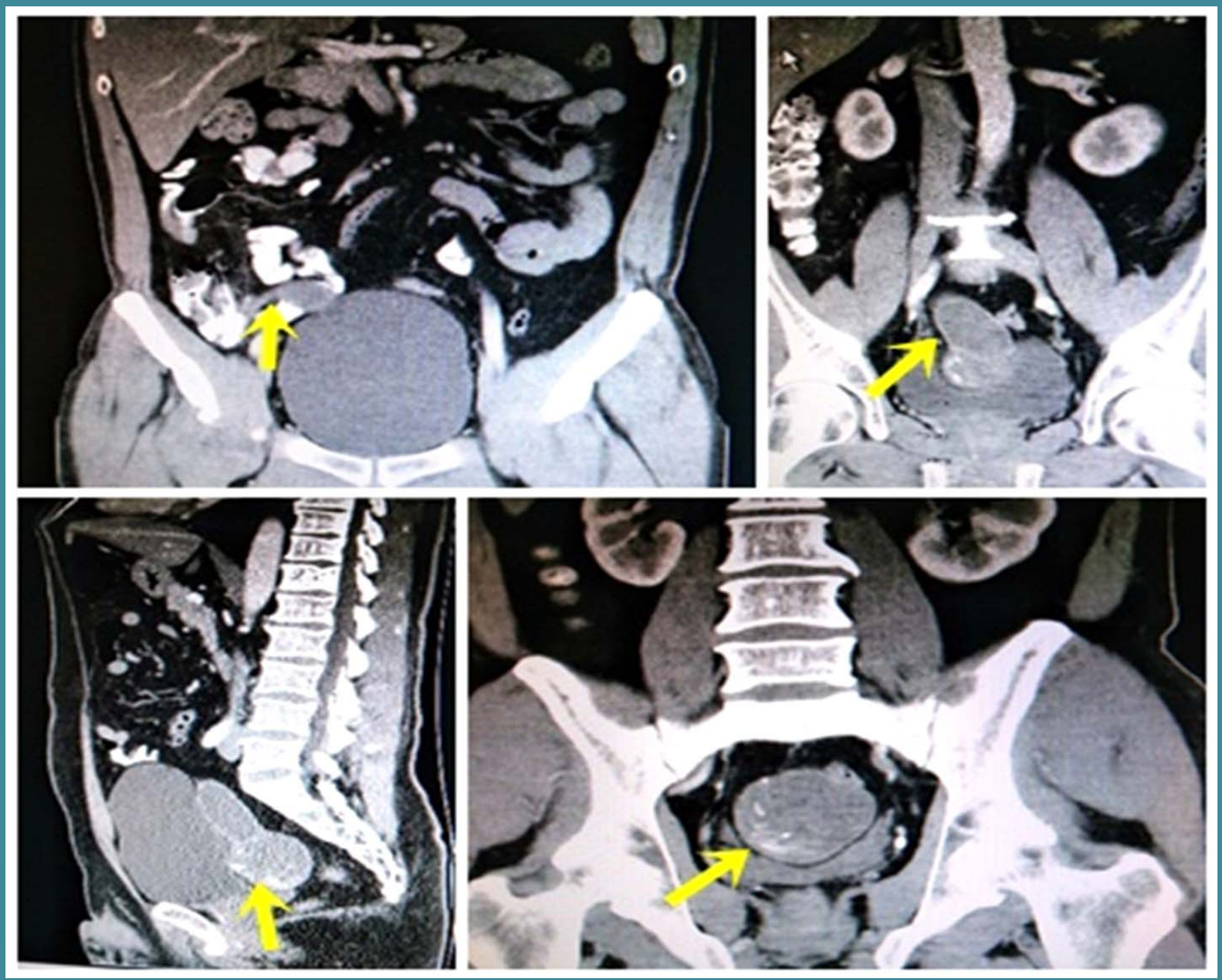

Figure 2. Abdominal-pelvic computed tomography showing appendiceal lesion extended retrovesical with a large tip with multiple calcifications 


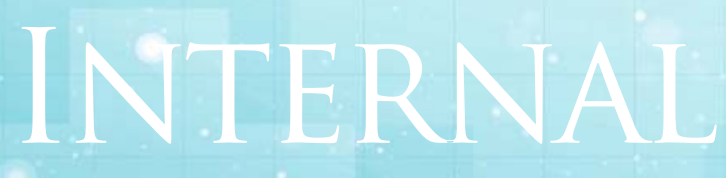

Clinical cases

neoplasms is the development of PMP (pseudomyxoma peritonei). This is mucinous ascites of the abdomen due to the dissemination of mucinous neoplastic cells throughout the peritoneal cavity. In $94 \%$ of cases of PMP, the source of these cells is a perforated appendiceal tumor. LAMN Type 2 lesions are more likely to result in PMP. As mucin fills the abdominal cavity, the omentum, bowel, spleen, ovary and myometrium may become invaded.

The management after correct staging according to the American Joint Committee on Cancer (AJCC) staging guidelines include initial surgery with resection of all appendiceal mucinous lesions for both diagnostic and therapeutic purposes standard appendectomy.

The decision to perform a more extensive resection than appendectomy is usually made intraoperatively or can be planned to obtain a clear margin.

It can involve a partial cecectomy (with preservation of the ileocecal valve), ileocecectomy (resecting the ileocecal valve), or right colectomy. Advanced-stage and/or ruptured appendiceal mucinous neoplasms may require additional surgical treatment beyond appendectomy: completion right hemicolectomy with lymphadenectomy or cytoreductive surgery (CRS) and heated intraperitoneal chemotherapy (HIPEC) to treat peritoneal mucinous disease (pseudomyxoma peritonei).

\section{Case presentation}

We present the case of a 49-year old male patient presented for epigastric pain, heart burns and non-specific diffuse abdominal pain for the last 3 weeks. The patient is known with hiatal hernia and Helicobacter pylori infection treated recently. Clinically, he was systematically well, vital signs unremarkable, abdomen unpainful upon palpation and normal bowel movements.

Laboratory tests showed modifications only at carcinoembryonic antigen (CEA) levels $(30,32 \mathrm{ng} / \mathrm{mL})$ and carbohydrate antigen 19$9(28,44 \mathrm{UI} / \mathrm{mL})$. Superior digestive endoscopy showed multiple small esophageal erosions of about $10-15 \mathrm{~mm}$, a small hiatal hernia and diffuse atrophic gastritis Helicobacter pylori negative. Colonoscopy performed for colorectal cancer screening does not reveal any significant changes of mucosa, with exception of swollen internal hemorrhoids.

Abdominal ultrasound indicated a nonhomogenous hypoechoic retrovesical tubular non-peristaltic lesion $13 \mathrm{~cm}$ long that was not suggestive for any common diagnosis. Abdominal computed tomography revealed hepatomegaly (cranio-caudal diameter of right hepatic lobe $18 \mathrm{~cm}$ ) and an 


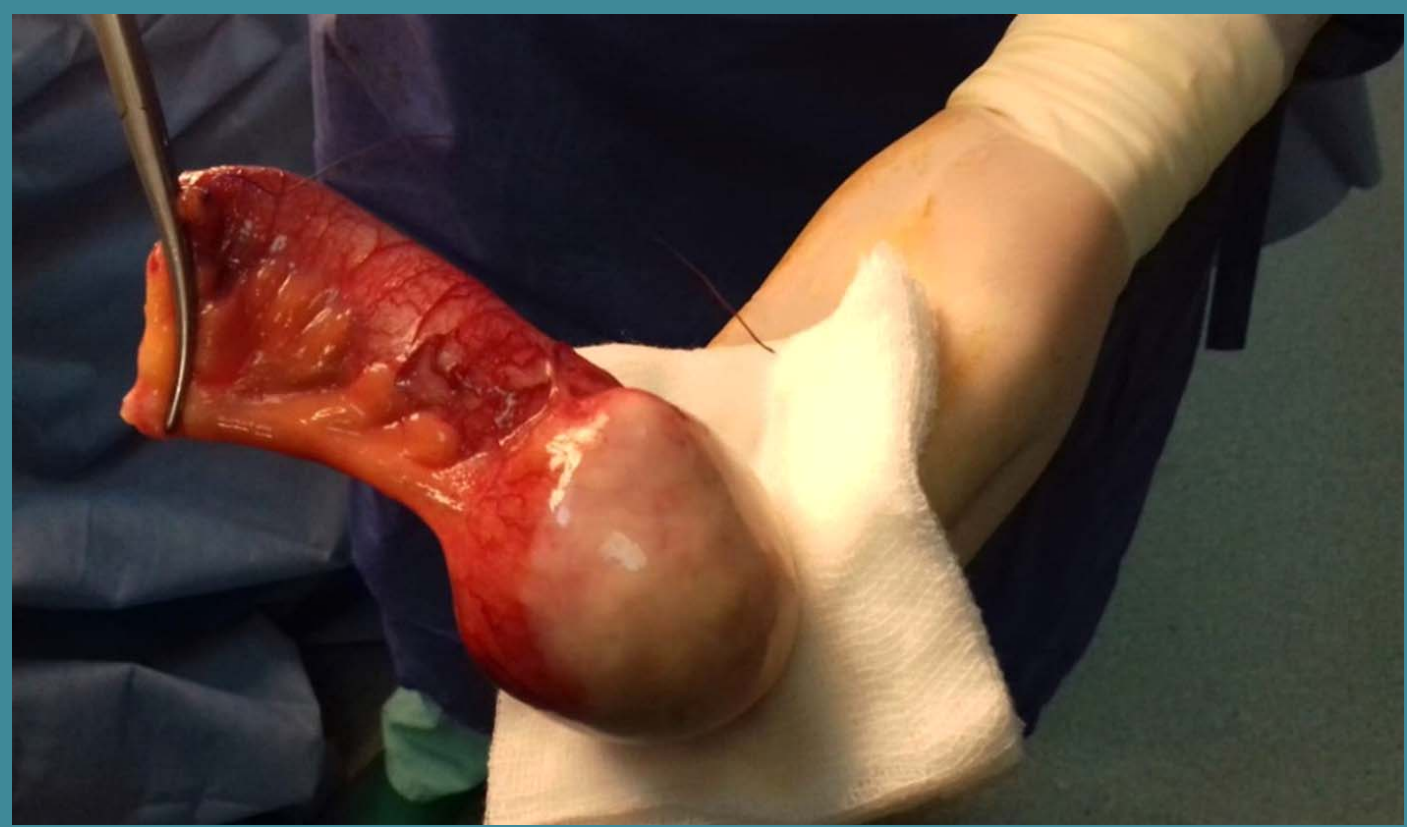

Figure 3. Macroscopic aspect of the resection piece

enlarged asymetric appendix $18 \mathrm{~cm}$ long with an increased transversal diameter at the top $(6,2 \mathrm{~cm})$, hypodense/fluid structure and multiple linear calcifications in the top of appendix situated retrovesically, suggesting a mucocele of the appendix.

A suspicion of uncomplicated mucinous appendiceal adenocarcinoma was made, so the patient underwent a retrograde appendectomy with peritoneal lymph nodes excision.

Pathological examination showed fragments of appendiceal wall with papillary epithelial proliferation in the mucosa with areas of distorted glands with hyper-chrome nuclei and increased mitotic activity, with invasions in the submucosa and muscularis mucosae with mucous spots and tumoral epithelial cells. Histopathological exam concluded for moderately differentiated mucinous appendiceal adenocarcinoma with infiltration of the muscular layer, without lymph node invasion on the peritoneal lymph node dissected. (pT3, pNx, pMx, G2).

After that, a right hemicolectomy was made with LL ileocolonic anastomosis with a good evolution. Laboratory test showed a decreased level of carcinoembryonic antigen (CEA): $1,9 \mathrm{ng} / \mathrm{mL}$ from $31,32 \mathrm{ng} / \mathrm{mL}$ and the pacient is under oncologic follow-up.

\section{Conclusions}

Primary adenocarcinoma of the appendix is exceedingly rare and frequently has an extremely poor prognosis because is diagnosed in advanced stages. In our paucisymptomatic patient, a simple abdominal ultrasound revealed the diagnosis path in an early stage. Given the possibility of neoplastic peritoneal dissemination, it should be considered as a diagnosis, especially in older females with non-specific symptoms similar to appendicitis. 


\section{References:}

1. Carr NJ, Bibeau F, Bradley RF, et al. The histopathological classification, diagnosis and differential diagnosis of mucinous appendiceal neoplasms, appendiceal adenocarcinomas and pseudomyxoma peritonei. Histopathology 2017; 71:847.

2. Săndica Bucurica, Florentina Ioniță Radu, Mariana Jinga, M.R. Voiosu- Leziunile neoplazice colorectalecadru conceptual si descriptiv-Medicina Interna/Internal Medicine, nr.3/2014:77-82

3. Marmor S, Portschy PR, Tuttle TM, Virnig BA. The rise in appendiceal cancer incidence: 2000-2009. J Gaastrointest Surg. 2015;19:743-92750. doi: 10.1007/s11605-014-2726-7.

4. Misdraji J. Mucinous epithelial neoplasms of the appendix and pseudomyxoma peritonei. Mod Pathol. 2015;28:S67-S79. doi: 10.1038/modpathol.2014.129.

5. Carr NJ, Bibeau F, Bradley RF, et al. The histopathological classification, diagnosis and differential diagnosis of mucinous appendiceal neoplasms, appendiceal adenocarcinomas and pseudomyxoma peritonei. Histopathology 2017; 71:847-58.

6. Valasek MA, Pai RK. An update on the diagnosis, grading, and staging of appendiceal mucinous neoplasms. Adv Anat Pathol 2018; 25:38-60.

7. Tang LH. Epithelial neoplasms of the appendix. Arch Pathol Lab Med 2010; 134:1612-20.

8. Dixit, J.H. Robertson, S.S. Mudan, C. Akle, Appendiceal mucocoeles and pseudomyxoma peritonei, World J. Gastroenterol. 13 (16) (2007) 2381 e2384.

9. Barrios P, Losa F, Gonzalez-Moreno S, Rojo A, Gómez-Portilla A, Bretcha-Boix P, Ramos I, Torres-Melero $J$, Salazar R, Benavides M, Massuti T, Aranda $E$, Recommendations in the management of epithelial appendiceal neoplasms and peritoneal dissemination from mucinous tumours (pseudomyxoma peritonei), Clin Transl Oncol. 2016;18(5):437. Epub 2015 Oct 21. 